$\mathrm{Nr} 2(65), 2020$, s. 257-271

https://doi.org/10.12797/Politeja.17.2020.65.18

\author{
Marta HOFFMANN (D) \\ Uniwersytet Jagielloński \\ marta1990.hoffmann@uj.edu.pl
}

\title{
MONGOLSKA MEDYCYNA TRADYCYJNA JAKO PRZESTRZEŃ POSTPAMIĘCI W PERSPEKTYWIE MEDYKALIZACJI
}

ABSTRACT Mongolian Traditional Medicine as a Space of Post-memory within Medicalisation Perspective

The main aim of the article is to check whether traditional medicine practice could be a possible code of post-memory. Supporting traditional medicine in modern Mongolia by the government and the World Health Organization seems to be an interesting example of such a combination. After spending a long time under the communist rule, Mongolian society returns to their traditional concept of health and illness. Traditional Mongolian knowledge defines the state of being healthy as a harmony of three elements: khii, šar and badgan. Treating a disease which is perceived as a state of imbalance between these elements is strongly intertwined with Buddhist tradition practised by healers who are called emchi. Restoring such concepts among Mongolian society after the dominance of biomedical model of health during communism could possibly be a sphere of post-memory.

Keywords: medicalisation, post-memory, traditional medicine, healers, sociology of medicine

Słowa kluczowe: medykalizacja, postpamięć, medycyna tradycyjna, uzdrowiciele, socjologia medycyny 


\section{WSTĘP}

Celem artykułu jest odpowiedzenie na pytanie o to, czy tradycyjne praktyki zdrowotne mogą stanowić formę kodu postpamięciowego. Odpowiedź zostanie udzielona przez analizę roli medycyny tradycyjnej we współczesnym społeczeństwie mongolskim. W czasach komunistycznych w mongolskiej opiece zdrowotnej dominował model biomedyczny, bazujący na przeświadczeniu o tym, że choroba spowodowana jest zaburzeniami w strukturze lub funkcji komórek, tkanek lub całych organów ${ }^{1}$. W konsekwencji, tradycyjne praktyki lecznicze miały być „zapomniane”, ponieważ u ich podstaw leżało pojmowanie jednostki na sposób holistyczny, czyli jako całość złożona z pierwiastków biologicznych, psychicznych i duchowych ${ }^{2}$. Współczesne wspieranie i dostrzeganie medycyny tradycyjnej w polityce zdrowotnej może być zatem przejawem społecznego „przypominania sobie” kulturowego dziedzictwa, które decyduje o mongolskiej tożsamości. Problem ten pozostaje szczególnie aktualny w związku z faktem, iż w 2018 roku minęło czterdzieści lat od ogłoszenia przez Światową Organizację Zdrowia Deklaracji $z$ Atma Aty postulującej zagwarantowanie podstawowej opieki zdrowotnej dla każdego. To na niej bazuje ogłoszona przez WHO w 2013 roku Strategia na rzecz Medycyny Tradycyjnej na lata 2014-2023. Ma ona za zadanie doprowadzić do nawiązania dialogu pomiędzy kulturowo uwarunkowaną wizją zdrowej jednostki a zachodnim (biomedycznym) rozumieniem dystynkcji zdrowie - choroba ${ }^{3}$.

\section{PROBLEM POSTPAMIECCI}

Wydawałoby się, że procesy medykalizacji mają niewiele wspólnego z pojęciem postpamięci. Na potrzeby artykułu postpamięć jest rozumiana jako przetworzona pamięć kulturowa, za pomocą której grupa społeczna podtrzymuje swoją tożsamość po traumatycznych dla niej momentach. Postpamięć jest zatem narracją budowaną na wspomnieniach poprzedniego pokolenia, która staje się częścią indywidualnego doświadczenia i przeżywania historii ${ }^{4}$. Znanym przykładem dyskursu postpamięciowego jest stosunek do Szoa potomków osób będących jej świadkami bądź ofiarami ${ }^{5}$. Nie jest to zatem

D.T. Wade, P.W. Halligan, Do Biomedical Models of Illness Make for Good Healthcare Systems?, „British Medical Journal" 2004, vol. 329, s. 1398.

2 J.S. Larson, The Conceptualization of Health, „Medical Care Research and Review” 1999, vol. 56, nr 2, s. 123-136.

3 Zob. WHO Traditional Medicine Strategy 2014-2023, Geneva 2013. Dokument dostępny na oficjalnej stronie WHO: https://apps.who.int/iris/bitstream/handle/10665/92455/9789241506090_ eng.pdf ? sequence=1, 1 VII 2019.

4 K. Goertz, Transgenerational Representations of the Holocaust: From Memory to "Post-Memory”, „World Literature Today" 1998, vol. 72, nr 1, s. 33-34.

5 Tamże, s. 33-38; M. Hirsch, Projected memory: Holocaust Photographs in personal and public fantasy, „Acts of Memory: Cultural Recall in the Present” 1999, vol. 8; A. Stein, Trauma and Origins: 
bezpośrednia pamięć opierająca się na rejestrowaniu bieżących wydarzeń, lecz pamięć skonstruowana, czyli mająca swe podstawy w przekazie ustnym bądź pisemnym. Postpamięć jest na potrzeby artykułu rozumiana zgodnie z jej definicją wypracowaną przez Marianne Hirsch ${ }^{6}$ i charakteryzuje się kilkoma cechami.

Po pierwsze, postpamięć dotyczy istotnych z punktu widzenia danej grupy wydarzeń $^{7}$. Są to zwykle wydarzenia bolesne, takie jak Szoa w przypadku Żydów czy skutki awarii reaktora w Czarnobylu dla społeczności zamieszkującej ogarnięte nimi tereny ${ }^{8}$. W tym sensie narracje postpamięci nie tylko sprawiają, że tego typu traumatyczne dla danej grupy przeżycia stają się częścią zarówno jej historii, ale także decydują o sposobie ich wyrażania9. Wynika to z faktu, iż przekaz uczestników wydarzeń jest na tyle silny, że w efekcie jednostki włączają te wydarzenia w swoje własne wspomnienia, czyniąc z nich elementy własnej historii życia. W rezultacie Szoa nie przechodzi jedynie do historii podręcznikowej, ale staje się doświadczeniem każdego Żyda bez względu na to, czy w nim osobiście uczestniczył, czy nie ${ }^{10}$. Postpamięć może jednak także dotyczyć innego typu wydarzeń. Zastosowana w ramach artykułu wspomniana już koncepcja medykalizacji ukazuje specyficzny kod postpamięci, jakim mogą być tradycyjne praktyki zdrowotne współczesnych Mongołów. Odnoszę ją zatem do specyficznej sytuacji, gdy postpamięć staje się narzędziem „przypominania sobie” tradycyjnego dziedzictwa kulturowego które, jeśli chodzi o system ochrony zdrowia, zostało „zapomniane" w czasie komunizmu w Mongolii. To tradycyjne dziedzictwo obejmuje w tym wypadku jedynie szczególny wycinek rzeczywistości społecznej, którym jest przestrzeń zdrowia i choroby. Postpamięć przyjmuje w artykule formę ponownego „przypominania sobie”, a co za tym idzie, przyjmowania za swoją narracji dotyczącej tradycyjnych sposobów definiowania integralności cielesnej i psycho-duchowej oraz jej możliwych zaburzeń. Kodem tak rozumianej postpamięci jest nie tylko język, którym posługują się tradycyjni mongolscy uzdrowiciele, ale także praktyki oraz przedmioty przez nich stosowane.

Po drugie, postpamięć ma charakter skonstruowany, co oznacza, że jest zakorzeniona w indywidualnych, a co za tym idzie, subiektywnych historiach osób uczestniczących $\mathrm{w}$ istotnych $\mathrm{z}$ punktu widzenia grupy wydarzeniach ${ }^{11}$. W związku z ich podobieństwem do siebie pod względem treści, a także ładunku emocjonalnego z nimi związanego, narracje będące środkiem przenoszenia postpamięci tworzą pewien uporządkowany

Post-Holocaust Genealogists and the Work of Memory, "Qualitative Sociology” 2009, vol. 32, nr 3, s. 293-309.

6 M. Hirsch, The Generation of Postmemory, „Poetics Today” 2008, nr 1, s. 103-128.

$7 \quad$ K. Goertz, Transgenerational Representations...

8 Por. A. Duda, Czarnobyl w strefie postpamięci. O narracji przewodnickiej Aleksandra Siroty - „Mera” Prypeci, „Politeja” 2017, nr 47, s. 201-213.

9 J. Assmann, J. Czaplicka, Collective Memory and Cultural Identity, „New German Critique” 1995, nr 65, s. 128-129.

$10 \quad$ K. Goertz, Transgenerational Representations...

11 M. Halbwachs, The Group in Its Spatial Framework. The Influence of the Physical Surroundings, [w:] tenże, The Collective Memory, New York 1950. 
wewnętrznie przekaz przejmowany następnie przez kolejne pokolenie danej grupy społecznej $^{12}$. W efekcie tego pokolenie to tworzy sobie własny, żywy emocjonalnie obraz wydarzeń, o których mowa, uznając go za część swoich historii życia, a co za tym idzie, „pamięta je”, chociaż nie było ich uczestnikiem ani obserwatorem. W kontekście poruszanego w artykule tematu medycyny tradycyjnej, konstrukcyjność pamięci przejawia się w uczestnictwie Mongołów w praktykach uzdrowicielskich, wiążących ich z kulturowym dziedzictwem tradycyjnych plemion mongolskich wyrugowanym w znacznej mierze w okresie komunizmu ${ }^{13}$. Wiedza współczesnych obywateli Mongolii na temat kwestii zdrowia i choroby została w znacznej mierze ukształtowana przez tzw. model biomedyczny stosowany w polityce zdrowotnej tego państwa w tym czasie ${ }^{14}$. Obecna działalność mongolskich uzdrowicieli, przy poparciu państwa, sprzyja nie tylko odnowieniu holistycznej koncepcji zdrowia i choroby we współczesnym społeczeństwie, ale także wyrażeniu swoistej ciąglości kulturowo-historycznej z jego przodkami. W związku z faktem, iz jest to przekaz nowy, ale bazujący na interpretacji tradycyjnych doświadczeń, to również ma on charakter skonstruowany.

Po trzecie, postpamięć ma charakter dynamiczny, co oznacza, że jej treści są ciągle kształtowane i nigdy nie stanowią zakończonej historii ${ }^{15}$. Traumatyczne przeżycia będące głównym przedmiotem postpamięci oddziałują bowiem na postrzeganie teraźniejszości przez osoby, które w nich uczestniczyły. Teraźniejszość z kolei może być bodźcem do przypominania sobie przeszłości, która w ten sposób podlega nieustannej reinterpretacji ${ }^{16}$. Artykuł traktuje o specyficznej formie przekazu postpamięciowego, jaką stanowią tradycyjne praktyki lecznicze na obszarze współczesnej Mongolii. Poprzez fakt, iż nawiązują one do holistycznych koncepcji zdrowia człowieka, z jednej strony łączą współczesne społeczeństwo mongolskie ze społeczeństwami tradycyjnymi, a z drugiej strony są widomym znakiem krzywdy, jaką ich rodzimej kulturze zadał system komunistyczny opierający się na radykalnie redukcjonistycznym modelu medycyny. Mnogość tradycyjnych praktyk leczniczych dostarcza wielu nowych form wyrazu postpamięci, a co za tym idzie, wpływa na jej dynamikę.

\section{KONCEPCJA MEDYKALIZACJI A POSTPAMIĘĆ}

Przyczyną postawienia pytania o to, czy praktyki lecznicze mogą być kodem postpamięci, jest swoisty zwrot, jaki dokonał się w socjologii, oznaczający rosnące zainteresowanie społecznymi podstawami wiedzy medycznej prowadzące do powstania tzw.

\section{Tamże.}

13 Ch. Kletter, S. Glasl, T. Thalhammer, S. Narantuya, Traditional Mongolian Medicine - A Potential for Drug Discovery, „Scientia Pharmaceutica” 2008, vol.76, nr 1, s. 51.

14 Tamże, s. 51-52.

15 M. Hirsch, The Generation of Postmemory...

16 Por. H. Brookfield, S.D. Brown, P. Reavey, Vicarious and Post-memory Practices in Adopting Families: The Re-production of the Past through Photography and Narrative, "Journal of Community and Applied Social Psychology" 2008, vol. 18, s. 474-491. 
socjologii medycyny. Jest to dziedzina, która wyewoluowała z badań socjologicznych prowadzonych w obrębie nauk medycznych i nazywana była „socjologią w medycynie" (ang. sociology in medicine) ${ }^{17}$. Badania tego typu miały charakter służebny wobec nauk medycznych i miały na celu rozwinięcie nowych form terapii poprzez usprawnienie komunikacji lekarz - pacjent ${ }^{18}$. Z czasem jednak okazało się, iż aby zrozumieć tę relację, należy sięgnąć do genezy powstania wiedzy medycznej, a to wymaga socjologicznego spojrzenia na wszelkiego rodzaju praktyki lecznicze obecne w kulturze zachodniej, a także na dystynkcję zdrowie - choroba. Jedną z pierwszych socjologicznych refleksji w tym duchu była koncepcja społecznej roli chorego autorstwa Talcotta Parsonsa, który wyliczył kilka podstawowych cech czyniących z choroby instytucję społeczną, takich jak zawieszenie chorego w wypełnianiu obowiązków, zobowiązanie społeczeństwa do pomocy mu, a także wymóg, by chory dążył do wyzdrowienia ${ }^{19}$. Kolejne prace na tym polu badawczym dotyczyły medycyny jako wiedzy społecznej i dały asumpt niektórym jej krytykom do podważania jej autorytetu w niektórych dziedzinach. Krytycy ci, znani jako przedstawiciele tzw. „ruchu antypsychiatrycznego”, twierdzili, iż psychiatria jest przykładem tej specjalności medycznej, której zasadniczym celem jest poddawanie kontroli oraz sankcjonowanie jednostek odróżniających się na tle innych ${ }^{20}$. Wskazywali oni, iż specjalność ta, bazując na płynnych i uznaniowych granicach między zdrowiem a chorobą w aspekcie psychicznym, w sposób nieuzasadniony podpiera się autorytetem medycyny, by poddawać społeczeństwo procesom normalizacji $^{21}$. Istotną książką, która mogła wzmacniać to przekonanie, były Instytucje totalne autorstwa Ervinga Goffmana, amerykańskiego socjologa i twórcy tzw. teorii dramaturgicznej w naukach społecznych. $\mathrm{Na}$ tej podstawie powstała koncepcja medykalizacji, rozumiana jako proces polegający na zmianie sposobu pojmowania niektórych fenomenów społecznych z niemedycznego na medyczny ${ }^{22}$. Pierwotna wersja tej koncepcji, bazująca silnie na antypsychiatryzmie, zakładała, że to lekarze i reszta personelu medycznego odpowiadają za ekspansję medycyny w inne sfery życia społecznego ${ }^{23}$. W połowie lat 80 . XX wieku koncepcja ta uległa wyraźnej zmianie, tracąc swój normatywny charakter. Jej zwolennicy zaczęli traktować medykalizację jako etykietę dla opisu zjawisk, które mają charakter społeczny. Mówiąc ściślej, zauważyli, że jednym z głównych motorów procesów medykalizacyjnych są same społeczeństwa, które w ramach koncepcji „światowego ryzyka” zmierzają swoimi działaniami do zapewnienia

17 W. Piątkowski, Geneza i przedmiot socjologii medycyny, [w:] Zdrowie i choroba. Wybrane problemy socjologii medycyny, red. J. Barański, W. Piątkowski, Wrocław 2002, s. 20-21.

18

19 A. Doroszewska, A. Sadowska, Mosty zamiast murów - socjologia medycyny przyktadem udanej (?) interdyscyplinarnej wspótpracy, „Nauka i Szkolnictwo Wyższe” 2013, vol. 41, nr 1, s. 59-60.

20 Por. R.J. Dubos, Miraże zdrowia. Utopie, postęp i zmiany biologiczne, przeł. T. Kielanowski, Warszawa 1962.

21 Por. T. Szasz, The Myth of Mental Illness. Foundations of Theory of Personal Conduct, London 1981.

22 P. Conrad, Medicalization and Social Control, „Annual Review of Sociology” 1992, vol. 18, s. 210.

23 M. Nowakowski, Medykalizacja i demedykalizacja. Zdrowie i choroba w czasach kapitalizmu zdezorganizowanego, Lublin 2015, s. 15-17. 
sobie jak najwyższego poziomu bezpieczeństwa ${ }^{24}$. Innymi istotnymi aktorami w tym procesie są korporacje farmaceutyczne, szeroko pojęte rynki wyrobów medycznych i farmaceutycznych, a także ruchy społeczne i organizacje pozarządowe zrzeszające pacjentów, osoby niepełnosprawne, a także te zmagające się z rzadkimi chorobami. Obecnie studia medykalizacyjne skupiają się na badaniach konkretnych przejawów procesów medykalizacyjnych obecnych zarówno w państwach o wysokim PKB, jak i w państwach rozwijających się.

Można zapytać o zasadność łączenia terminu „postpamięć” z terminem „medykalizacja”. Z jednej strony bowiem postpamięć odnosi się do sytuacji przechowywania i rekonstrukcji traumatycznej historii pewnych grup społecznych, podczas gdy medykalizacja stanowi opis procesów związanych z konkretną sferą życia współczesnych społeczeństw. Postpamięć bazuje przede wszystkim na indywidualnych narracjach dotyczących historycznych wydarzeń, podczas gdy medykalizowanie jest długotrwałym procesem społecznym. O ile postpamięć dotyczy pewnych traumatycznych wydarzeń w historii pewnych grup społecznych, o tyle medykalizacja odnosi się raczej do fenomenów o charakterze uniwersalnym, takich jak seksualność, starość, nadpobudliwość, stres itd. ${ }^{25} \mathrm{Z}$ drugiej strony jednak obydwa pojęcia oznaczają konstrukcję społeczną opartą na opisie pewnego wycinka rzeczywistości oraz praktykach, które podtrzymują ten opis. Obydwa pojęcia związane są z aktywistyczną postawą społeczeństw i dotyczą zmian w pojmowaniu wydarzeń bądź zjawisk. W przypadku postpamięci mamy do czynienia z płynnością granic pomiędzy wydarzeniami historycznymi a indywidualnymi przeżyciami, a w przypadku medykalizacji chodzi o płynność granic między zdrowiem i chorobą. Mając na uwadze te podobieństwa, postanowiłam zadać w artykule pytanie o wzajemne związki między nimi oraz zaproponować ostrożnie sformułowaną odpowiedź na nie. Na przykładzie mongolskiej medycyny tradycyjnej chciałabym pokazać, iż medykalizacja może być kodem postpamięci.

\section{TRADYCYJNA MEDYCYNA MONGOLSKA JAKO PRZESTRZEŃ POSTPAMIĘCI. PODSTAWOWE ZAŁOŻENIA MONGOLSKIEJ MEDYCYNY TRADYCYJNEJ}

Mongolska medycyna tradycyjna ukształtowała się około XVI wieku, a jej głównymi propagatorami byli buddyjscy lamowie, czerpiący swoją wiedzę ze świętych tekstów. Przemierzali oni stepowe tereny państwa mongolskiego, lecząc i uzdrawiając chorych.

24 Por. A. Clarke, J. Shim, Medicalization and Biomedicalization Revisited: Technoscience and Transformations of Health, Illness and American Medicine, [w:] Handbook of the Sociology of Health, Illness, and Healing: A Blueprint for the 21 $1^{\text {st }}$ Century, red. B.A. Pescosolido, J.K. Martin, J.D. McLeod, A. Rogers, New York 2011, s. 173-199.

25 Zob. P. Conrad, Identifying Hyperactive Children. The Medicalization of Deviant Behavior. Expanded Edition, Routledge 2017; Posttraumatic Stress Disorder, red. G.M. Rosen, Wiley 2004; A.C. Saguy, K.W. Riley, Weighing Both Sides: Morality, Mortality, and Framing Contests over Obesity, „Journal of Health Politics, Policy and Law" 2005, vol. 30, nr 5, s. 869-921. 
Określano ich terminem emchi, a nazwa ta tak mocno przylgnęła do praktyki uzdrowicielskiej, że z czasem zaczęto nią określać mongolskich medyków w ogóle, a współcześnie oznacza ona po prostu lekarza ${ }^{26}$. Cała wiedza działających dzisiaj w Mongolii tradycyjnych uzdrowicieli opiera się na założeniach, zasadach i doświadczeniach wypracowanych w ciągu kilku wieków przez lamów, a następnie przekazywanych w tradycji ustnej. Warto też nadmienić, iż tradycja ta nie pozostawała w oderwaniu od innych wpływów kulturowych, przede wszystkim tybetańskich i chińskich ${ }^{27}$. Mimo różnorodności praktyk uzdrowicielskich w Mongolii, naznaczonych silnie tradycjami lokalnymi, mongolska medycyna tradycyjna charakteryzuje się kilkoma cechami decydującymi o jej wewnętrznej spójności.

Po pierwsze, tak jak w przypadku innych praktyk uzdrowicielskich, jednostka jest pojmowana w sposób holistyczny. W odróżnieniu od zachodniego, biomedycznego modelu, w którym choroba jest postrzegana przez pryzmat zaburzeń funkcjonowania organów ${ }^{28}$, na gruncie medycyny mongolskiej ciało i duch są ze sobą nierozerwalnie związane $^{29}$. W efekcie tego wszelkie zaburzenia związane ze stroną duchową znajdują swoje odzwierciedlenie w zaburzeniach funkcjonowania ciała i na odwrót. W związku z tym głównym zadaniem emchi jest przywrócenie właściwego funkcjonowania zarówno ducha, jak i ciała. W tym celu, zanim podejmą się oni postawienia diagnozy, przeprowadzają nie tylko badanie fizykalne poprzez dotykanie różnych części ciała chorego, ale także rozmawiają z nim, aby ustalić duchowe przyczyny problemu i powiązać je $\mathrm{z}$ dolegliwościami cielesnymi ${ }^{30}$.

Po drugie, ważną cechą mongolskiej medycyny tradycyjnej jest przeświadczenie o tym, że organizm człowieka składa się z trzech podstawowych pierwiastków, czyli wiatru (khii), żółci (šar) i flegmy $(\text { badgan })^{31}$. Šar i badgan są wobec siebie przeciwstawne. Pierwszy pierwiastek jest kojarzony z ciepłem i suchością. Odpowiada on temu, co w tradycji chińskiej przypisuje się pierwiastkowi yang $^{32}$. Drugi element jest kojarzony z zimnem oraz wilgocią i odpowiada temu, co określa termin $y i n^{33}$. Khii jest z kolei pierwiastkiem pośredniczącym między nimi, a jego zadaniem jest równoważenie ich ${ }^{34}$. Człowiek

26 Ch. Kletter, S. Glasl, T. Thalhammer, S. Narantuya, Traditional Mongolian Medicine..., s. 52-55.

27 T.-H. Kim, L. Basargard, J.-I. Kim, M.-S. Lee, Mongolian Traditional Style Blood-Letting Therapy: A Brief Introduction, „Complementary Therapies in Clinical Practice” 2011, vol. 17, s. 179-180. Jest to pewne uproszczenie, które odzwierciedla jedynie „klasyczną” wersję orientacji biomedycznej. Współczesna definicja zdrowia bierze pod uwagę także psychospołeczne aspekty zdrowia, co odzwierciedla cytowana w artykule Konstytucja Światowej Organizacji Zdrowia. Por. T. Wade, P.W. Halligan, Do Biomedical Models of Illness...

29 A. Pitschmann i in., Traditional Mongolian Medicine: History and Status Quo, „Phytochemistry Review" 2013, vol. 12, s. 943-945.

30 J.A. Bernstein i in., Use of Traditional Medicine in Mongolia: A Survey, „Complementary Therapies in Medicine" 2002, vol. 10, nr 1, s. 42-45.

31 A. Pitschmann i in., Traditional Mongolian Medicine..., s. 52-55.

32 Tamże.

33 Tamże.

34 Tamże. 
zdrowy charakteryzuje się zbalansowaną obecnością wszystkich wspomnianych elementów. W sytuacji, gdy równowaga między nimi zostaje zaburzona, górę przejmuje jeden z dwóch przeciwstawnych pierwiastków, powodując swoiste dolegliwości cielesne. I tak, nadmiar żółci skutkuje gorączką, kaszlem czy suchością oczu i ust, podczas gdy nadmiar flegmy powoduje gromadzenie się wody w organizmie i problemy z metabolizmem. Jeśli z kolei w organizmie gromadzi się zbyt dużo khii, pojawiają się problemy z oddychaniem oraz mową. W niektórych tradycjach uzdrowicielskich jako przyczynę problemu zdrowotnego wskazuje się brak okazywania należytego szacunku duchom przodków ${ }^{35}$. Zadaniem uzdrowiciela jest zatem przywrócenie naturalnej równowagi organizmu poprzez oddziaływanie nań substancjami roślinnymi lub zwierzęcymi o właściwościach przeciwnych do tych, które wykazuje szkodliwy w nadmiarze pierwiastek.

Po trzecie, charakterystyczne jest również przekonanie o tym, że emchi musi samodzielnie wytwarzać mieszanki, którymi się posługuje, zgodnie ze swoją wiedzą czerpaną z ksiąg, tradycji ustnej i własnych doświadczen ${ }^{36}$. Ta sama zasada dotyczy tzw. bariachi, czyli osób, które nastawiają kości ${ }^{37}$. Z zasady zioła i materiały pochodzenia zwierzęcego, takie jak sproszkowane kości lub rogi, muszą być zbierane w terenie, na którym działa uzdrowiciel. W ostateczności, jeśli zabraknie mu jakiegoś składnika, musi on samodzielnie wyruszyć na jego poszukiwanie. Wszystko odbywa się zgodnie z przeświadczeniem, iż człowiek i jego środowisko naturalne stanowią nierozerwalną całość, w związku z czym oddziaływanie na chorą jednostkę substancjami z obcego dla niej terenu może skończyć się nawet pogorszeniem jej stanu zdrowia.

Po czwarte, istotną rolę w procesie diagnozy i leczenia odgrywa przeświadczenie o znaczeniu płynów ustrojowych oraz pulsu osoby chorej. Uzdrowiciel musi rozróżniać różne rodzaje pulsu świadczące o źródle i rodzaju choroby ${ }^{38}$. W tym celu dotyka on szyi lub ramion pacjenta, a następnie określa cechy jego moczu i krwi, by następnie móc zdiagnozować jego chorobę. Podstawowymi ich formami są: stosowanie mieszanek ziołowych, rozgrzewanie lub ochładzanie części ciała dotkniętych chorobą, okadzanie i upuszczanie krwi.

Po piąte, szczególną rolę w procesie leczenia odgrywa cielesny kontakt pomiędzy uzdrowiciele a chorym, a także przeświadczenie o tym, że chory ma znaczącą kontrolę nad swoją chorobą ${ }^{39}$. Częstą praktyką stosowaną w mongolskiej medycynie tradycyjnej są różne rodzaje masaży z użyciem ziół i stosowanych na dolegliwości bólowe. Jednocześnie, dzięki temu, że uzdrowiciel zwykle zna dobrze chorego oraz jego rodzinę, w proces leczenia włączony jest szerszy krąg osób niż w przypadku orientacji

35 D.J. Hruschka, Baria Healers Among the Buriats in Eastern Mongolia, „Mongolian Studies” 1998, vol. 21, s. 20-39.

36 T.-H. Kim, L. Basargard, J.-I. Kim, M.-S. Lee, Mongolian Traditional Style Blood-Letting Therapy..., s. 181-183.

37 Sh. Bold, Brief History and Development of Traditional Mongolian Medicine, WIPO, [online] https://www.wipo.int/edocs/mdocs/tk/en/wipo_iptk_bkk_09/wipo_iptk_bkk_09_topic6_1.pdf, 1 VII 2019.

38 Tamże.

39 Tamże. 
biomedycznej. Rytuał wzmacnia tym samym relacje między członkami grupy, a także tożsamość chorego jako jej członka.

\section{WSPÓŁCZESNA RECEPCJA TRADYCYJNYCH PRAKTYK LECZNICZYCH NA TERENIE MONGOLII}

W chwili, gdy Mongolia dostała się w strefę wpływów Związku Radzieckiego w 1924 roku, wszystkie obszary polityki tego państwa przeniknęła doktryna komunistyczna, opierająca się na materialistycznym oglądzie świata widzianym przez pryzmat sił produkcyjnych i kapitału, a także pojęcia konfliktu klasowego ${ }^{40}$. Narracja ta odmawiała miejsca holistycznemu ujęciu problemów zdrowia i choroby ${ }^{41}$. W tym czasie trwały nasilające się co pewien czas represje wobec mnichów buddyjskich, których działalność została całkowicie zakazana. Obowiązująca ideologia wyłączała ze sfery publicznej wszelkie przejawy stosowania tradycyjnych praktyk leczniczych, stawiając w ich miejsce medycynę bazującą na leczeniu środkami farmakologicznymi ${ }^{42}$. Płynne granice między zdrowiem a chorobą były nierzadko przesuwane tak, by pokrywały się z granicami pomiędzy zwolennikami i przeciwnikami obowiązującego ustroju politycznego, o czym świadczy politycznie motywowane osadzanie tych drugich w szpitalach psychiatrycznych ${ }^{43}$. Ziołolecznictwo i działalność uzdrowicieli nadal jednak istniały, ale były ukrywane z obawy przed możliwymi represjami ${ }^{44}$. Wydaje się, że ich obecność była nie tylko formą sprzeciwu wobec komunistycznej ideologii, ale także aktem swoistego zaufania kulturowo ukształtowanej wiedzy. Można to także traktować jako indywidualną manifestację przywiązania do tradycji kulturowej oraz łączności ze światem, który przeminął wraz z nastaniem nowej epoki.

Mongolia uzyskała niepodległość w 1990 roku, a już w 1992 roku uchwalona została nowa, demokratyczna konstytucja ${ }^{45}$. Zmiany te pozwolity na ponowne wprowadzenie medycyny tradycyjnej w sferę publiczną. Fakt, iż w tym samym roku mongolskie władze uchwaliły I Program na rzecz Medycyny Tradycyjnej ${ }^{46}$ świadczy nie tylko o tym, że w poprzedniej epoce nie udało się osłabić przywiązania do lokalnych tradycji zdrowotnych, ale także o tym, iż we współczesnym świecie medycyna tradycyjna wciąż pozostaje bardzo ważnym komponentem grupowej tożsamości Mongołów. Co interesujące, Mongolia jest jedynym państwem wśród wszystkich członków Światowej

40 S. Manaseki, Mongolia: a health system in transition, „British Medical Journal” 1993, vol. 307, s. 1609-1611.

$41 \quad$ Sh. Bold, Brief History and Development...

42 Tamże.

43 S. Manaseki, Mongolia: a Health System...

44 Tamże.

45 Ch. Kletter, S. Glasl, T. Thalhammer, S. Narantuya, Traditional Mongolian Medicine..., s. 55-58.

46 WHO, Mongolia Health System Review, „Health Systems in Transition” 2013, vol. 3, nr 2, s. 126, [online] https://apps.who.int/iris/bitstream/handle/10665/207531/9789290616092_eng.pdf?sequence=1, 1 VII 2019 . 
Organizacji Zdrowia, które tak dużo uwagi poświęca dialogowi medycyny konwencjonalnej i tradycyjnej. Warto wyliczyć kilka cech tego dialogu, który może stanowić mechanizm tworzenia postpamięci. Po pierwsze, charakteryzuje się on silnym poparciem i zapleczem politycznym. Oznacza to, iż w przeciwieństwie do innych państw, praktyki medycyny tradycyjnej nie są domeną działalności niektórych ruchów społecznych i charyzmatycznych jednostek, ale stanowią jeden z podstawowych elementów oficjalnej mongolskiej polityki zdrowotnej ${ }^{47}$. Mongolskie ministerstwo zdrowia nie tylko konstruuje programy poświęcone wspieraniu tradycyjnych uzdrowicieli, ale także wspiera ich kształcenie poprzez tworzenie instytutów badawczych zajmujących się naukowym badaniem produktów pochodzenia roślinnego, których ci używają ${ }^{48}$. Dzięki temu ukształtowana kulturowo wiedza na temat człowieka jako psychofizycznej całości żyjącej w harmonii ze środowiskiem naturalnym, a także praktyki zdrowotne z niej wynikające nie są traktowane jako swego rodzaju „dziwactwo”, ale jako istotny społecznie nośnik historii i tradycji przekazywanej z pokolenia na pokolenie. W przeciwieństwie do wielu państw zachodnich, gdzie medycyna tradycyjna nie jest zwykle częścią systemów ochrony zdrowia, w Mongolii uzdrowiciele są traktowani tak samo, jak lekarze $^{49}$. Poparcie dla ich działalności stanowi oficjalny symbol szacunku względem kulturowych korzeni Mongołów. Nie oznacza to wszakże, iż medycyna tradycyjna zajęła miejsce medycyny konwencjonalnej. Stanowi raczej komplementarny element dla medycyny zachodniej w mongolskiej polityce zdrowotnej.

Po drugie, dialog ten charakteryzuje się dużą otwartością na międzynarodową wymianę informacji. Mongolia pozostaje aktywnym partnerem Światowej Organizacji Zdrowia w tej sferze jej działalności, jaką jest medycyna tradycyjna ${ }^{50}$. Wiele dokumentów WHO poświęconych medycynie tradycyjnej nie tylko wspiera tworzenie jednostek zgłębiających naukowo jej tajniki, ale nawet stawia Mongolię za przykład kraju ${ }^{51}$, w którym dialog ten przynosi owoce w postaci coraz większej liczby uzdrowicieli zwiększających zasięg swojego oddziaływania. Szczególnie warto zwrócić uwagę na postawę uzdrowicieli, którzy, z jednej strony, chronią przekazane wcześniej dziedzictwo kulturowe, a z drugiej, chcą poddawać je analizie i reinterpretacji, godząc się na to, by kształcić się w zakresie medycyny konwencjonalnej oraz poddawać naukowym badaniom substancje, których używają ${ }^{52}$. W tym sensie modyfikują oni przekaz kulturowy, który otrzymali, włączając w niego dyskurs naukowy, a następnie wykorzystują go w procesie leczenia. W efekcie tego ich wiedza i sposób postrzegania swojej roli oraz praktyk jest kombinacją tradycyjnych przekazów i ich współczesnej reinterpretacji ${ }^{53}$.

\section{Tamże.}

WHO, Regulatory situation of herbal medicines: a worldwide review, 1998, s. 134.

WHO, Mongolia Health System Review.

Tamże.

WHO Traditional Medicine Strategy 2014-2023, Geneva 2013, s. 29.

B. Gerke, Tradition and Modernity in Mongolian Medicine, „Journal of Alternative and Complementary Medicine" 2004, vol. 10, nr 5, s. 743-749.

Tamże. 
Po trzecie, medycyna tradycyjna cieszy się sporą popularnością wśród współczesnych Mongołów uważających ją za ważny komponent praktyki lekarskiej ${ }^{54}$. Prowadzone w tym obszarze badania pokazały, że w niektórych sferach, takich jak zdrowie psychiczne czy problemy natury neurologicznej, Mongołowie chętniej uciekają się do wiedzy i rady emchi. O ile w społeczeństwach zachodnich medycyna jest jednym z narzędzi opanowywania ryzyka i niebezpieczeństwa na poziomie biologicznym, o tyle w społeczeństwie mongolskim medycyna stanowi dodatkowo swoiste narzędzie bezpieczeństwa kulturowego dynamicznie adaptowanego do współczesności.

\section{PRAKTYKI MONGOLSKIEJ MEDYCYNY TRADYCYJNEJ JAKO KOD POSTPAMIĘCI}

Analizując niektóre formy tradycyjnych praktyk uzdrowicielskich w Mongolii, okazuje się, że można je wpisać w trzy poziomy medykalizacji wyróżnione przez Petera Conrada: konceptualny, instytucjonalny i interakcyjny ${ }^{55}$. Jednocześnie na każdym z tych poziomów tworzy się i jest podtrzymywany społeczny kod, dzięki któremu wytwarzana jest postpamięć.

Poziom konceptualny medykalizacji oznacza, iż obserwowana współcześnie zmiana postrzegania pewnych fenomenów ze sfery niemedycznej na medyczną odbywa się za pomocą objęcia ich pojęciami medycznymi w taki sposób, że bądź funkcjonują one jako jednostki chorobowe (aspekt negatywny), bądź też, szerzej, są włączane w dyskurs zdrowotny (aspekt pozytywny) ${ }^{56}$. Dzięki temu procesowi niektóre problemy zdrowotne (np. nadmierny stres, głęboki smutek, nadpobudliwość, otyłość) stają się możliwe do kontrolowania. W Mongolii poziom korzystania z usług zdrowotnych stale rośnie, przez co Mongołowie częściej mają okazję zetknąć się z medycyną tradycyjną ${ }^{57}$, co można traktować jako jeden z przejawów medykalizacji. Dzięki tym kontaktom społeczeństwo mongolskie nie tylko staje się bardziej uwrażliwione na swój stan zdrowia, ale także ma okazję zetknąć się z kulturowo wypracowaną wiedzą uzdrowicielską. Mongolski rząd nie tylko wspiera kształcenie uzdrowicieli oraz instytuty badawcze zajmujące się medycyną tradycyjną, ale także daje subwencje budżetowe na niektóre tradycyjne usługi zdrowotne, przez co są one tańsze i bardziej dostępne ${ }^{58}$. Jednocześnie, aby uzdrowiciel lub lekarz legitymujący się odpowiednim kursem w zakresie medycyny tradycyjnej mógł prowadzić swoją działalność, powinien on stosować te substancje, które zostały odpowiednio sprawdzone pod kątem bezpieczeństwa dla pacjenta. Tego typu testowanie jest z kolei wspierane przez Światową Organizację Zdrowia, która pomaga i zachęca państwa do tworzenia instytutów badawczych, w których będzie można zbadać zioła

\footnotetext{
54 J.A. Bernstein i in., Use of Traditional Medicine in Mongolia...

55 P. Conrad, Medicalization and Social Control, „Annual Review of Sociology” 1992, vol. 18, s. 210-211.

56 Tamże, s. 212.

57 WHO, Mongolia Health System Review...

58 Tamże, s. 98-127.
} 
oraz określić ich właściwości ${ }^{99}$. W efekcie tego w Mongolii nadawane są naukowe i angielskie nazwy tradycyjnym leczniczym roślinom ${ }^{60}$, a także miejscom w ciele ludzkim, które są przedmiotem leczenia, jak Zulain sugas (głowa, nad linią włosów) czy Zosnii sharin sugas (przedramię) ${ }^{61}$. Wszystko to sprawia, że tradycyjne przekonania o tym, jakie są przyczyny choroby, zyskują oficjalną aprobatę nie tylko krajową, ale także międzynarodową. Możliwość skorzystania z tej wiedzy medycznej kontrastuje z czasami komunistycznymi, gdy dziedzictwo medycyny tradycyjnej było przekazywane przez uzdrowicieli w ukryciu. Wysiłki, by przywrócić tradycyjne mongolskie rozumienie chorób, można zatem potraktować jako odpowiedź na konieczność jego „zapominania" w mongolskim systemie opieki zdrowotnej.

Poziom instytucjonalny medykalizacji dotyczy zwiększenia liczby instytucji medycznych, a także postępującej specjalizacji wiedzy medycznej, która obejmuje współcześnie coraz szersze spektrum problemów (takich jak np. nieśmiałość, starość, zaburzenia snu czy niedoskonałości ciała) ${ }^{62}$. Instytucjonalizacja tradycyjnej mongolskiej wiedzy medycznej polega z kolei na zwiększaniu liczby instytucji, takich jak uniwersytety i ośrodki badawcze, $\mathrm{w}$ których przebiega kształcenie z zakresu tradycyjnych praktyk leczniczych ${ }^{63}$. Co więcej, uzdrowiciele dostają możliwość wyjazdów za granicę, w czasie których upowszechniają swoją wiedzę i spotykają się z innymi tradycjami, szczególnie herbalistycznymi ${ }^{64}$. Instytucjonalizacja polega zatem na zwiększeniu liczby ośrodków pogłębiających i propagujących wiedzę na temat tradycyjnego mongolskiego ujęcia zdrowia i choroby. Uzdrowiciele zyskują w ten sposób możliwość odbywania zagranicznych podróży i promowania nie tylko kulturowego dziedzictwa, ale także rodzimych sposobów leczenia. Interesujące jest też to, że mongolskie władze pozwalają na tworzenie nie tylko ośrodków badawczych, ale także prywatnych praktyk i szpitali, w których Mongołowie mogą korzystać z medycyny tradycyjnej ${ }^{65}$. Poprawa dostępności tych usług jest kolejnym elementem zbliżającym mongolskie społeczeństwo do swojego kulturowego dziedzictwa i jednocześnie widocznym odejściem od restrykcyjnych zasad stosowanych wobec uzdrowicieli w minionej epoce. Jeśli w czasach komunistycznych uzdrowiciele spotykali się z represjami oraz zakazami prowadzenia działalności, to obecnie można obserwować proces przywracania pamięci o ich roli w tradycyjnym społeczeństwie mongolskim. Można powiedzieć, że stają się oni

59 Por. WHO Traditional Medicine Strategy 2014-2023..., s. 30-42; WHO, Report of WHO. Interregional Workshop on the Use of Traditional Medicine in Primary Health Care (raport WHO ze spotkania w Ułan Bator w dniach 23-26 VIII 2007 roku), s. 13-27, [online] https://apps.who.int/iris/ bitstream/handle/10665/44008/9789241597425_eng.pdf ?sequence=1\&isAllowed=y, 1 VII 2019.

60 WHO, Guidelines on the Conservation of Medicinal Plants, Geneva 1993, [online] http://apps.who. $\mathrm{int} /$ medicinedocs/documents/s7150e/s7150e.pdf, 1 VII 2019.

${ }^{61}$ Por. WHO, Research Guidelines for Evaluating the Safety and Efficacy of Herbal Medicines, Geneva 1993, [online] http://apps.who.int/medicinedocs/en/d/Jh2946e/5.1.1.html, 1 VII 2019.

62 Tamże.

63 WHO, Mongolia Health System Review..., s. 116-137.

64 Tamże.

65 B. Gerke, Tradition and Modernity in Mongolian Medicine... 
ważnymi osobami, które przechowują zapomnianą, ale istotną z punktu widzenia Mongołów wiedzę.

Poziom interakcyjny medykalizacji dotyczy sytuacji, gdy choroba staje się faktem poprzez interakcję pomiędzy lekarzem a pacjentem ${ }^{66}$. W jej trakcie pacjent z jednej strony utwierdza się w przekonaniu, że znajduje się po którejś stronie granicy zdrowy - chory, a lekarz podejmuje działania wynikające z usytuowania tam pacjenta. Przykładem tej sytuacji jest, stawiany za wzór przez WHO, projekt Family Pharmacy Kit wspierany przez japońską fundację Nippon ${ }^{67}$. Jego zadaniem jest dostarczenie każdej mongolskiej rodzinie, bez względu na jej miejsce zamieszkania, zestawu niezbędnych leków, wśród których znajdują się także rośliny i inne substancje lecznicze ${ }^{68}$. W efekcie tego każdy obywatel Mongolii ma możliwość bezpośredniego zetknięcia się z medycyną tradycyjną, nawet jeśli z niej nie korzysta. Takie pakiety rozprowadzają wolontariusze bądź uzdrowiciele, dzięki czemu rodzina ma możliwość zapoznać się z podstawowymi zasadami ziołolecznictwa. Oprócz tego, że dzięki takim działaniom całe rodziny są zaopatrzone w niezbędne leki, to dodatkowo są to leki zgodne z kulturowo wypracowaną wiedzą oraz pochodzące z terenów Mongolii, co znów sprawia, że stają się one bardziej dostępne. I po raz kolejny widoczny jest w tym wypadku kontrast $\mathrm{z}$ sytuacją w epoce komunistycznej, ponieważ wtedy chory był zmuszony przyjść do lekarza, a dziś - mówiąc obrazowo - lekarstwa same „przychodzą” do Mongołów. Nawet jeśli rodzina nie korzysta z usług uzdrowicieli, ma ona możliwość w ten sposób „przypomnieć sobie" swoje tradycyjne dziedzictwo.

\section{PODSUMOWANIE}

Podsumowując, należałoby zapytać, czy zasadne jest włączanie koncepcji medykalizacji do refleksji nad współczesnymi kodami postpamięci. Argumentem przeciw jest to, że zarysowane praktyki mongolskiej medycyny tradycyjnej oraz działania rządu mongolskiego i WHO o wiele bardziej wpisują się w pamięć kulturową obejmującą nie tyle wydarzenia, ile całokształt wiedzy zgromadzonej w pewnej konkretnej sferze życia ludzkiego. Ponadto, przekaz, którym dysponują uzdrowiciele, nie jest związany bezpośrednio z traumą równą Szoa w przypadku Żydów. Represje względem buddyjskich mnichów w okresie komunistycznym zostawiły pewnie bolesny ślad w pamięci ich współczesnych pobratymców, jednak to nie one stanowią przedmiot postpamięciowego przekazu. W tym sensie praktyki medycyny tradycyjnej nie kwalifikują się do oznaczenia etykietą nośników postpamięci. Z drugiej jednak strony, w dobie poszerzania definicji i sposobów rozumienia postpamięci, propozycja potraktowania wspomnianych wyżej praktyk jako nowego jej kodu nie jest bezzasadna, bowiem przywracają one i czynią widocznym kulturowo ukształtowane dziedzictwo społeczeństw tradycyjnych po długim okresie

66 Tamże.

67 Report of WHO. Interregional Workshop..., s. 54-58.

68 Tamze. 
jego politycznego „zapomnienia”. Nie ma powodu, aby powtarzanych z sukcesem inicjatyw włączenia medycyny tradycyjnej w szereg filarów współczesnej polityki zdrowotnej w Mongolii nie nazwać próbami oficjalnego „przypomnienia” społeczeństwu mongolskiemu jego tożsamości, a tym samym - upatrywać w nich kolejnego kodu postpamięci.

\section{BIBLIOGRAFIA}

Assmann J., Czaplicka J., Collective Memory and Cultural Identity, „New German Critique” $1995, \mathrm{nr} 65$.

Bernstein J.A. i in., Use of Traditional Medicine in Mongolia: a survey, „Complementary Therapies in Medicine" 2002, vol. 10, nr 1, https://doi.org/10.1054/ctim.2002.0508.

Bold Sh., Brief History and Development of Traditional Mongolian Medicine, WIPO, [online] https://www.wipo.int/edocs/mdocs/tk/en/wipo_iptk_bkk_09/wipo_iptk_bkk_09_topic6_1.pdf, 1 VII 2019.

Clarke A., Shim J., Medicalization and Biomedicalization Revisited: Technoscience and Transformations of Health, Illness and American Medicine, [w:] Handbook of the Sociology of Health, Illness, and Healing: A Blueprint for the $21^{\text {st }}$ Century, red. B.A. Pescosolido, J.K. Martin, J.D. McLeod, A. Rogers, New York 2011, https://doi.org/10.1007/978-1-4419-7261-3_10.

Conrad P., Identifying Hyperactive Children. The Medicalization of Deviant Behavior. Expanded Edition, Routledge 2017.

Conrad P., Medicalization and Social Control, „Annual Review of Sociology” 1992, vol. 18, https://doi.org/10.1146/annurev.so.18.080192.001233.

Doroszewska A., Sadowska A., Mosty zamiast murów - socjologia medycyny przyktadem udanej (?) interdyscyplinarnej wspótpracy, „Nauka i Szkolnictwo Wyższe” 2013, vol. 41, nr 1.

Dubos R.J., Miraże zdrowia. Utopie, postęp i zmiany biologiczne, przel. T. Kielanowski, Warszawa 1962.

Duda A., Czarnobyl w strefie postpamięci. O narracji przewodnickiej Aleksandra Siroty - „Mera” Prypeci, „Politeja” 2017, vol. 47, https://doi.org/10.12797/Politeja.14.2017.47.15.

Gerke B., Tradition and Modernity in Mongolian Medicine, „Journal of Alternative and Complementary Medicine" 2004, vol. 10, nr 5, https://doi.org/10.1089/1075553042476614.

Goertz K., Transgenerational Representations of the Holocaust. From Memory to "PostMemory”, „World Literature Today” 1998, vol. 71, nr 1, https://doi.org/10.2307/40153531.

Halbwachs M., The Group in Its Spatial Framework. The Influence of the Physical Surroundings, [w:] tenże, The Collective Memory, New York 1950.

Hirsch M., Projected memory: Holocaust photographs in personal and public fantasy, „Acts of Memory: Cultural Recall in the Present" 1999, vol. 8.

Hirsch M., The Generation of Postmemory, ,Poetics Today” 2008, nr 1.

Hruschka D.J., Baria Healers Among the Buriats in Eastern Mongolia, „Mongolian Studies” 1998, vol. 21.

Kim T.-H. i in., Mongolian Traditional Style Blood-Letting Therapy: A Brief Introduction, "Complementary Therapies in Clinical Practice” 2011, vol. 17, https://doi.org/10.1016/j. ctcp.2010.11.002. 
Kletter Ch., Glasl S., Thalhammer T., Narantuya S., Traditional Mongolian Medicine A Potential for Drug Discovery, „Scientia Pharmaceutica” 2008, vol. 76, nr 1, https://doi. org/10.3797/scipharm.0802-04.

Larson J.S., The Conceptualization of Health, „Medical Care Research and Review” 1999, vol. 56, nr 2, https://doi.org/10.1177/107755879905600201.

Manaseki S., Mongolia: a Health System in Transition, „British Medical Journal” 1993, vol. 307, https://doi.org/10.1136/bmj.307.6919.1609.

Nowakowski M., Medykalizacja i demedykalizacja. Zdrowie i choroba w czasach kapitalizmu zdezorganizowanego, Lublin 2015.

Pitschmann A. i in., Traditional Mongolian Medicine: History and Status Quo, „Phytochemistry Review" 2013, vol. 12, https://doi.org/10.1007/s11101-013-9321-5.

Posttraumatic Stress Disorder, red. G.M. Rosen, Wiley 2004.

Saguy A.C., Riley K.W., Weighing Both Sides: Morality, Mortality, and Framing Contests over Obesity, "Journal of Health Politics, Policy and Law” 2005, vol. 30, nr 5, https://doi. org/10.1215/03616878-30-5-869.

Stein A., Trauma and origins: Post-Holocaust Genealogists and the Work of Memory, „Qualitative Sociology" 2009, vol. 32, nr 3, https://doi.org/10.1007/s11133-009-9131-7.

Szasz T., The Myth of Mental Illness. Foundations of Theory of Personal Conduct, London 1981. Wade D.T., Halligan P.W., Do Biomedical Models of Illness Make for Good Healthcare Systems?, „British Medical Journal” 2004, vol. 329, https://doi.org/10.1136/bmj.329.7479.1398.

WHO, Guidelines on the Conservation of Medicinal Plants, Geneva 1993.

WHO, Mongolia Health System Review, „Health Systems in Transition” 2013, vol. 3, nr 2.

WHO, Regulatory Situation of Herbal Medicines: a Worldwide Review, 1998.

WHO, Report of WHO. Interregional Workshop on the Use of Traditional Medicine in Primary Health Care (raport Światowej Organizacji Zdrowia ze spotkania w Ułan Bator w dniach 23-26 VIII 2007 roku), [online] https://apps.who.int/iris/bitstream/handle/10665/ 44008/9789241597425_eng.pdf ?sequence=18isAllowed=y, 1 VII 2019.

WHO, Research Guidelines for Evaluating the Safety and Efficacy of Herbal Medicines, Geneva 1993.

WHO Traditional Medicine Strategy 2014-2023, 2013.

Zdrowie i choroba. Wybrane problemy socjologii medycyny, red. J. Barański, W. Piątkowski, Wroclaw 2002.

Mgr Marta HOFFMANN - doktorantka w Instytucie Nauk Politycznych i Stosunków Międzynarodowych Uniwersytetu Jagiellońskiego w Krakowie. Przygotowuje rozprawę doktorską z zakresu politycznego zastosowania medykalizacji przez Światową Organizację Zdrowia. Jej zainteresowania naukowe obejmują: wielopłaszczyznowe relacje między sferą polityki i medycyny, biopolityczną interpretację relacji państwo - obywatel, teorie stosunków międzynarodowych, w szczególności konstruktywistyczne. Od lutego 2018 roku prowadzi projekt badawczy pt. „Strategie medykalizacyjne Światowej Organizacji Zdrowia”, dofinansowany przez Narodowe Centrum Nauki w konkursie PRELUDIUM. 